\title{
ARE MEDIA REPORTS REPRESENTATIVE OF HOST COMMUNITY SUPPORT FOR MEGA-EVENTS? THE CASE OF SYDNEY WORLD YOUTH DAY 2008
}

\author{
MIRRIN LOCKE and ANNE ZAHRA \\ Department of Tourism and Hospitality, The University of Waikato, Hamilton, New Zealand
}

\begin{abstract}
World Youth Day 2008 (WYD08) held during July was the fourth mega-event to be held in Sydney in the past decade. All mega-events, such as WYD08, attract considerable media attention in the lead up to, during, and after the event. In the lead up to WYD08, media reports, particularly those in the Australian written press, were predominately negative. These reports gave the impression that there was little, if any, support for holding the event among the residents of Sydney. Data were collected through a combination of document analysis and host community interviews, in the lead up to, during, and immediately following the event. The document analysis included two local Sydney newspapers and one national newspaper. The findings show that printed media reports were not an accurate reflection of community support. Given that media is believed to be not only influenced by public opinion, but also capable of influencing public opinion, why was there such disparity between media reports and other sources of evidence regarding community support for this event? There is a call for more research investigating if what is reflected in the media is a fair approximation of community response to events.
\end{abstract}

Key words: Mega-event; Media reporting; Media bias; Host community perceptions; Residents' support

\section{Introduction}

Intense competition for valuable tourism income has lead to destinations seeking ways to not only attract tourists but to differentiate themselves. This has led to events being an integral part of many destinations tourism strategies (Getz, 1997) and the City of Sydney is no exception (Events NSW, n.d.). "Mega-events, by way of their size or significance, are those which yield extraordinarily high levels of tourism, media coverage, prestige, or economic impact for the host community or destination" (Getz, 1997, p. 6). Mega-events are recognized for the benefits they bring to a destination, in terms of exposure and profile raising of the destination (Jeong \& Faulkner, 1996), and long-term tourism and economic benefits (Hall, 1992). 
In recent years there has been a focus on the impact that tourism, including event tourism, has on the local community. Research has explored the impacts that events have on local residents, with some studies going on to examine residents support for the staging of events (Deccio \& Baloglu, 2002; Fredline \& Faulkner, 2001; Gursoy \& Kendall, 2006). These studies have used survey methodologies to assess the degree to which the local community is supportive of hosting an event. This article examines if the media can be used as another indicator of the impact of an event on a community.

There is substantial body of literature regarding the link between public opinion and the media. Media is seen as having dual roles in regard to public opinion (Hoffman, Glynn, Huge, Sietman, \& Thomson, 2007; Mitrook, 2003). In some instances the media can be a reflection of public opinion (Moala, 2005), while in other cases it can serve to influence public opinion (Vliegenthart, Schuck, Boomgaarden, \& De Vreese, 2008). Regardless of the function media is serving, there is clearly a link between public opinion, support, and media reporting. Somewhat surprisingly, there is very little research in the tourism and events literature examining the link between community support for tourism and the media. This article explores this link.

Community support for events is driven by individuals within the community's assessment of the costs and benefits of hosting the event. In order for an individual to assess perceived costs and benefits they drawn on three sources of information: direct experience, social interactions, and the media (Fredline \& Faulkner, 2001). Mega-events by their very nature attract significant media attention and provide an important source of information to host communities regarding costs and benefits they will receive from an event. What has not been previously examined is if what is reflected in the media is a fair approximation of community response to the event. This article seeks to address this gap by examining whether media reports are reflective of community support for one mega event; World Youth Day 2008.

The event being examined, World Youth Day, was held in Sydney during July 2008 and was aimed at people ages 16 to 35 years. World Youth
Day is an event organized by the Catholic Church to allow young people to share and celebrate their Christian faith. World Youth Day has been celebrated annually since 1984 . Despite this being the 10th occasion on which World Youth Day has been celebrated outside of Rome, with most of these events post-1990 involving between 1,000,000 and 4,000,000 participants (Sydney Chamber of Commerce, 2008), there has been very little research conducted on the event, and none published in English language sources from a Tourism or Event Management perspective.

This article commences with a review of the literature on community support for events, media reporting of events, and the relationship between the media and public opinion. The next section describes the qualitative research methods of text analysis and interviews that were used to collect the data. The findings section is followed by the discussion and conclusion sections showing that the community was generally supportive of the event but this was not reflected in the media.

\section{Community Support for Mega-Events}

Obtaining and maintaining host community support for mega-events is increasingly being acknowledged as an important part of the megaevent planning process, and for the success of the event (Gursoy \& Kendall, 2006; Hall, 1992; S. S. Kim \& Petrick, 2005). Host community or local support is simply the degree to which residents of the host community support the event. The more local residents support the event, the less they are likely to display behaviors that make the event planning and staging process more complex and difficult. Disgruntled local residents can stage protests, vote against officials, and in some cases even take legal action, all of which hamper the planning process both in terms of time and costs (Fredline, 2004; Gursoy \& Kendall, 2006; Hall, 1992). A supportive local community is more likely to be involved with and in some cases even take ownership of the event. This enhances the event by providing local flavor and even turning the event into an urban festival, which in turn improves the experience of the event for both visitors and residents alike (Fredline, 2004; Hall, 1992; Hiller, 1995). 
Community support for tourism can be explained using social exchange theory, whereby individual community members assess the perceived benefits costs and if they believe the benefits outweigh the costs they are likely to support tourism development. While mega-events result in a concentration of impacts compared to other types of tourism development, support for an event can be explained the same way (Deccio \& Baloglu, 2002; Fredline \& Faulkner, 2001; Gursoy \& Kendall, 2006; Lim \& Lee, 2006).

Mega-event impacts can be divided into three broad categories: economic (Burton, 2003; Kasimati, 2003); sociocultural (Hall \& Hodges, 1996; Ritchie, 2000); and environmental (Hede, 2007a), and perceived as either costs or benefits (Getz, 2007). Falkheimer (2007) found that costs and benefits to the community formed the basis of "letters to the editor" sections in the written press. Fredline and Faulker (2001) used social representation theory to examine resident reactions to two major motorsport events held in the Gold Coast and Melbourne, Australia. Communities gain images, preconceptions, and values through direct experience, social interaction, and the media. "Where direct experience is low there is a tendency to rely more heavily on the other two sources" (Fredline \& Faulkner, 2001, p. 121). This then influences how individuals perceive the costs and benefits that accrue as a result of the event being hosted in a community. They found that most residents surveyed were supportive of the continuation of the event. They also found that high levels of contact with the event led to more extreme attitudinal positions, while those with low levels of contact tended to be more ambivalent. It could be argued from the findings of this study that direct experience has a stronger effect on opinion than social interaction and media reporting. However, this study was silent on the impacts of the media.

Several authors have examined local residents' perception of the impacts of specific mega-events and concluded that these perceptions can and do change over time (e.g., Jeong \& Faulkner, 1996; S. S. Kim \& Petrick, 2005; Lim \& Lee, 2006; Twynam \& Johnston, 2004). S. S. Kim and Petrick (2005) examined the residents of Seoul's perceptions of the impacts of the 2002 FIFA World Cup using during and after survey of the host population. They found that residents' perceptions of some of the positive benefits were not as strong 3 months after the event as during the event. Twynam and Johnston (2004) found similar changes to perceptions when examining the host community in Thunder Bay, Canada, and their reaction to the hosting of the 1995 Nordic World Skiing Championship. They found that residents generally perceived impacts prior to the event to be greater than what actually accrued. They also found that community support for hosting the event prior to the actual event was strongly influenced by the perceptions of organization and readiness of the bodies involved in planning for and hosting the event.

The studies discussed above have used a quantitative survey methodology to determine the degree to which the community is supportive of hosting the event. This article adopts a qualitative methodology to evaluate if media reporting of the event can be used to determine community support for the event.

\section{Media Reporting of Mega-Events}

Mega-events by their nature attract significant amounts of media attention, both during the planning phase and the actual event itself. As a result mega-events are widely acknowledged within the literature as an opportunity for a destination to showcase itself to the world via the media coverage of the event (Bowdin, Allen, O'Toole, Harris, \& McDonnel, 2006; Burton, 2003; Chalip, 2004; Hall, 1992, 2001; Hede, 2007b; Johnsen, Bieger, Elsasser, \& Muller, 2004; Kang \& Perdue, 1994; H. J. Kim, Gursoy, \& Lee, 2006; Lee, Lee, \& Lee, 2005; Morgan, Pritchard, \& Pride, 2002; Reid, 2006; Toohey \& Veal, 2007; Whitson \& Macintosh, 1993). This is one of the main attractions for a destination to host a mega-event and, in some cases such as the Olympics, results in an intense bidding war for the right to host the event. Numerous authors have examined the specific impact that mega-events have had on the perception of the destination: for exmple, Custadio and Gouveia (2007) and their examination of the UEFA EURO 2004 held in Portugal; Rivenburgh, Louw, Loo, and Mersham's (2004) study of the impact of the Sydney Olympics on perception of Australia by 
residents in Hong Kong, Malaysia, South Africa, and the US; and Reid's (2006) examination of the effect of hosting the MTV music awards on the image of Edinburgh.

It has also been acknowledged that the planning phase for a mega-event usually generates some controversy and negative attention from the mass media (Gursoy \& Kendall, 2006; Hall, 1992). With intense competition in the mass media market, the use of an unusual angle or some form of sensationalism is often used to break through the "noise" in the marketplace and attract the attention of consumers (Bowdin et al., 2006; Getz, 1997). A prime example of this occurring can be found in relation to the Sydney 2000 Olympics where the media attention before the event was clearly focused on issues such as the IOC bribery scandal, ticketing issues, the beach volleyball venue saga, and the use of foreign marching bands (Toohey \& Veal, 2007).

\section{Media Reporting and Public Perception}

Interestingly there has been little attention paid to the relationship between the media and the host community in relation to mega-events or even tourism more generally. Two exceptions are Allon's (2004) study of the impact of backpackers within Sydney and Scott and Smith's (2005) examination of Schoolies week at the Gold Coast, Queensland. Both of these Australian studies made reference to the increasing number of media reports and the declining community support for these types of tourism.

Falkheimer (2007) while examining the effect that the Malmö-Skåne Louis Vuitton Acts $6 \& 7$ of the 32nd America's Cup-Valencia, had on destination image also touched on the concept of local and regional media reporting. He concluded that much of the current thinking regarding events and media coverage is oversimplified and does not take into account the level at which the media reporting is occurring, the character of the event and the news management strategies being utilized. He also found that in the case of this event the destination itself received very little attention in the national and international press. However, at the regional and local level there was significantly more focus on the destination and the impact of the event on it.

Outside the realm of tourism, there is extensive literature linking public perception and the mass media. Much of this literature is in relation to political issues (in particular US Presidential campaigns) (D'Alessio, 2003). Hoffman et al. (2007) examined the effects that intrapersonal, social, and media filters have on the formation of public opinion. They found that the media has dual roles. The first of these roles is as a disseminator of information and public opinion. The second is as an influencer and shaper of public opinion through the information it provides and coverage and attention of specific issues. Similarly, Mitrook (2003) in his longitudinal analysis of foreign policy and the media in the US found that media is an indicator of public opinion as well as having an influence on public opinion.

Two important theories explain the way in which mass media influences public opinion: 1) agenda setting and 2) issue framing. Agenda setting can be viewed as the gate keeping role in which the mass media plays. Editorial discretion determines the issues that receive coverage and the amount of attention received. This then affects public awareness of and knowledge about issues (Perry, 1996). Framing is simply put the manner in which issues are presented to public by the mass media. The emphasis is placed on some aspects of an issue, the language used, and the inferences drawn during coverage of an issue all affect the way the information that the public receives and can affect the way in which particular issues are viewed within the community (Rosenberry \& Vicker, 2009). In relation to political issues, where we have limited or no direct experience with it, the mass media becomes an important source of information. We use this information along with what information we have from other sources in forming opinions (Vliegenthart et al., 2008). It has also been found that the more consonant media coverage is on an issue, the more influential it is on public opinion (Peter, 2004).

Herbst (2001) and Moala (2005) both expressed the opinion that media reports should reflect public opinion. Herbst (2001), in examining the reflection of public opinion in nontraditional sources such as films, says that the American pub- 
lic opinion infrastructure means that public opinion is measured through polls and then disseminated through the media. Moala (2005) believes that media should be like a mirror, reflecting what is going on in peoples' lives, what they are doing, and the issues that are affecting them.

\section{World Youth Day 2008}

World Youth Day 2008 (WYD08), held from Tuesday July 15 to Sunday July 20, 2008, is the fourth mega-event to be held in Sydney in the past decade. The previous mega-events hosted in Sydney were the 2000 Olympic Games, the 2003 Rugby World Cup, and Asia Pacific Economic Cooperation Meeting in 2007. Based on visitor numbers WYD08 is comparable with the Sydney 2000 Olympic Games. The Sydney Olympics attracted an almost identical number of international visitors specifically there to attend the event (Price Waterhouse Cooper, 2002) although WYD2008 was smaller in terms of duration, organization, volunteers, and media.

There were 223,000 pilgrims registered for WYD08. There were 110,000 international visitors, representing over 170 nations; 40,000 of these pilgrims were billeted with host families, 12,000 camped at Sydney Olympic Park, and the balance stayed at one of the 700 temporary accommodation sites in government and nongovernment schools (World Youth Day 2008, 2008). In addition there were 8,000 volunteers, over 4,000 clergy, and 2,000 accredited media involved in WYD08 (World Youth Day 2008, 2008). World Youth Day 2008 consisted of 450 events held at over 100 venues over the 6-day period of the festival. The major Sydney CBD venues for events included Hyde Park, The Domain, Sydney Opera House, Darling Harbor, and Circular Quay (World Youth Day Coordination Authority, 2008).

The largest impact and disruption to residents was the Pilgrimage walk over the Sydney Harbor Bridge to Randwick Racecourse on Saturday the 19th with road closures and disruption to public transport (World Youth Day Coordination Authority, 2008). Initial legislation for the governance of WYD was introduced to and passed by the NSW State Parliament in November 2006 establishing the World Youth Day Coordination Authority whose principal function were to coordinate and manage the delivery of integrated government services for WYD08 events (Parliament of New South Wales, 2006). Just before the event, July 1, the New South Wales State Government amended the WYD Act to include an antiannoyance clause, which made it illegal to do anything that caused annoyance or inconvenience to participants in a World Youth Day event (New South Wales Government, 2008). These regulations were challenged in the federal court on July 15 and found to be invalid (Evans vs. State of New South Wales, 2008). There was significant government support for the event but this regulation and its consequent appeal highlights government concerns over tensions between residents and participants. The organizers of the event did not think this regulation was necessary (Powell, 2008).

\section{Methodology}

This investigation analyzed media reports and interviews with community members. Taking into consideration Falkheimer's (2007) findings regarding the differences in coverage of events by national and local newspapers, the investigation focused on two local newspapers and one national daily. WYD2008 newspaper articles from the Sydney Morning Herald (local), the Daily Telegraph (local), and the Australian (national with a large daily circulation in Sydney) were analyzed. The Sydney Morning Herald and the Daily Telegraph were selected as they are the main daily Sydney newspapers. The Australian is the national newspaper with a high distribution within Sydney. Articles from these papers were sourced from the EBSCO database Australian/New Zealand Reference Center which provided the complete text of these newspapers.

Articles published prior to July, the whole month of July 2008, and after the event were analyzed using content analysis. Articles were separated by publication and then further broken down into categories of publication before, during, and after WYD08. Consonance of coverage by each publication throughout the month and between publications was also assessed. Each author, separately, used content analysis to identify categories that integrate and generalize major themes. The 
authors then came together for comparison and to confirm the common themes emerging from the data. An inductive approach to the data analysis was used, whereby a set of categories grounded in the data were established so that key themes emerged (Strauss \& Corbin, 1990). This approach was chosen to mitigate any potential participant observer bias as a consequence of one of the author's participation in the event. Priori themes, themes that are expected to emerge, were also identified from the theory prior to the content analysis (Bazeley, 2003). Additional emergent themes were also discovered during the analysis.

In this study priori themes identified from the literature, which were expected to be evident in media reports, were:

1. Informative articles regarding event proceedings.

2. Costs to residents including congestion, inconvenience, restricted access, and economic costs.

3 . Benefits to residents including increased tourism, media exposure, job creation, sense of pride, celebration, happiness, and sense of belonging.

4. Sensationalism by the media.

During the process of content analysis several issues not related to the event, but tied to the event by the media also emerged. These issues included claims of previous sexual abuse by Catholic clergy, religious beliefs of politicians and government officials, and an anti-Catholic sentiment held by some members of the local community. These issues were used by media to create sensation and therefore break through the media "noise."

In addition to the content analysis of articles from these newspapers, the "letters to the editor" sections were also reviewed for evidence of community support or lack of community support for the event. While "letters to the editor" are selected and published according to the bias of the particular media to which they are addressed, as previously noted in the community support for events literature, residents' discontent is often expressed through this channel.

Further evidence of the level of community support for the event was found in the poll that was taken in the days immediately after the event.
This poll was conducted by Galaxy Research, a major market research company located in Chatswood, Sydney (Galaxy Research, n.d.), and Pureprofile, a company that provides online one to one marketing and market research through the use of user profiles (Pure Profile, 2009). The poll of 500 residents took place on Tuesday July 22 and Wednesday July 23, 2008. The results of this poll were weighted and projected to reflect the population of Sydney and reported in the Daily Telegraph on July 24. A summary of the results of this poll are included in the findings section of this article.

One of the researchers was in Sydney from July 10 to July 21 as part of the WYD Research Team, and undertook interviews with local Sydney community members and people working with the event, using purposeful and convenience sampling (Creswell \& Plano Clark, 2007) and diarized observations. Interviews were transcribed and content analysis again used to elicit themes.

\section{Findings}

\section{Media Exposure Prior to July 1, 2008}

WYD08 received considerable media attention from as early as July 2005 when Sydney submitted a bid for the hosting of the 2008 event. In September of 2006 it was recognized that Olympic Park was not large enough to host the final event for which 400,000 people were expected and Randwick Racecourse was announced as the preferred site on October 6, 2006. The reaction of the horse racing community was not positive. The media picked up on this. This was further confounded by the Equine Influenza epidemic that occurred in mid 2007. Even after the epidemic was over, the financial cost to taxpayers of relocating the racing industry for this event was a point of particular attention, chiefly negative, by the media.

The initial introduction of legislation to NSW State Parliament in November 2006 received very little media attention.

\section{Media Exposure July 1-14, 2008}

Local Media. In the lead up to the event The Sydney Morning Herald (SMH) was predominately negative in their coverage of issues related 
to event. The focus of their attention was primarily on the antiannoyance laws that were passed for the event. During the 14 days leading up to the event some 14 articles and 27 letters to the editor were published on this topic, indicating this topic was being used to create sensation. Articles ranged from outright criticism of the laws as an infringement of human rights and this being a burden for Sydney residents, to more comical approaches of suggesting t-shirt slogans that residents should not wear. Other articles criticized the event on the cost of hosting it both in terms of tax-payer funding and the impact on trade in the city center, the pilgrim numbers estimates, the billeting arrangements for pilgrims, and the impact that congestion and road closures would have for residents. The SMH gave substantial media space to the sexual abuse scandals in the Catholic Church both internationally and in Australia and ideological criticism of the Catholic Church and linked these debates to WYD2008.

The Daily Telegraph, in contrast to the SMH, was very positive in their coverage of issues and events in the lead up to WYD08. This is not surprising given their status as official newspaper for the event. This newspaper also contained the most articles regarding WYD08 and included special lift out sections on both Saturday the 12th and Sunday the 13th. There were also numerous feature articles on topics such as site preparation, feeding the pilgrims, Catholicism, and the history of the Vatican. In the sport section on July 2, there was an article stating there were no problems with the extra horses relocated from Randwick to Warwick Farm Racecourse and there was a minibus transporting employees from Randwick and that they were provided with a free hot breakfast. Overall the tone was positive and several articles specifically noted the perceived negativity within the community as reported by the SMH and urged readers to see the event for the benefits it would provide. Interestingly the letters to the editor section contained very few letters relating to the event. What letters were there were by and large supportive of the event with one letter stating that "Sydney is a city of whingers" and another stating that "the anti-annoyance laws were outrageous."

National Media. The Australian was predominately positive in their reporting of issues in the 2- week lead up to the event. The majority of articles included in the "News" section of the newspaper presented a neutral account of events and covered a range of issues including the threatened rail strike, road closures, and impact on commuters, arrival of pilgrims, and the Pope's in-flight media conference and arrival in Sydney. The feature articles were overtly positive regarding the event: "Barring the unforeseen, the Weekend Australian predicts World Youth Day will be a resounding success that should make Australia proud" ("Ancient Pilgrim Path," 2008). The expected economic benefits and media exposure from the event were also included. A major theme that emerged during the analysis was the criticism of other media, particularly $A B C$ radio and television, and the $S M H$ and to a lesser extent The Age, for their negativity towards the event and misrepresentation of the facts. Specific television programs were named and journalists identified as having prejudices and biases. One article dated July 11th stated that the SMH were leaders of the "protest" against WYD2008 and without their media sensationalism very few would have noticed (Devine, 2008). This debate was picked up by the readers, two letters to the editor published on July 14th commented on this, Kevin Rugg of Beaumaris, Victoria said "It is a national disgrace that these influential media organs have actively sought to undermine World Youth Day, an Australian Christian festival of world importance" ("Letters to the Editor," 2008) while Hank Verhoeven of Beacon Hill, NSW said "These past few months there have been many blatant manifestations of irritation, and of undiluted hatred as well regarding WYD and the Catholic church, especially in the print media" ("Letters to the Editor," 2008).

Community Feedback. Sydney International Airport experienced long queues and some delays through immigration, which would have inconvenienced locals and other visitors, yet there was a carnival atmosphere. Visitors and local residents returning from trips overseas went along with the entertainment and caught onto the cheerful atmosphere. One visitor commented "When I found out my time in Sydney was going to coincide with WYD I thought I had better get out, now that I am here it looks like it is going to be a party, I might 
change my mind and stay." The only disgruntled returning resident the researcher encountered was on the queue waiting to collect the rental car. He commented that he wanted to get home to get some sleep as he had been on a plane for 24 hours. He was anti-WYD because he was gay. The Pope refuses to agree with his choice of life and therefore he was just anti the Pope and Catholics. He also added that "the pilgrims in customs annoyed me with their singing, their American accents, and speaking Spanish." His comments indicate that were some members of the local community that were anti the event based on its Catholic nature.

Custom officials and airport staff commented that the pilgrims have been arriving in large numbers all week but they had never seen so many cheerful people. One employee commented that "a group from Croatia were still smiling and singing even though their luggage was left in London and half their group were stuck in Hong Kong. These types of tourists have made working here this last week a breeze."

The pilgrim group the researcher was attached to undertook some volunteer work packing food packs for the final event. Most of the volunteers were local residents, from a diverse range of ethnic groups and predominantly Catholic. These residents were saying "Sydney is very lucky to have this event" and "WYD is great for us as it is an opportunity to revitalize our faith." These residents, primarily Catholic, appeared too positive about the event, due to the benefit they saw of having the opportunity to celebrate their faith.

The following comment from a barista in the city summarizes the comments received from central business district operators. "Yeah business is great for a Saturday; you pilgrims are great for Sydney." One elderly lady said to a group in the cafe "Welcome, I hope you have a great time." The researcher asked her views on WYD and her reply was "I am glad that Sydney is hosting this and welcoming the pilgrims. I think the ones that are complaining are just selfish and it is the media that just focuses on the negative. I think society is too individualistic and people are only concerned about their own things. I think it is great that we open up our homes and our city."

\section{Media Exposure During the Event}

Local Media. Articles provided by the Daily Telegraph during WYD were firmly focused on the event itself. The common theme was that Sydneysiders had become swept up in the joyous nature of the event, "Happy mood overcoming Sydney" (July 16). Letters to the editor during this period were mostly positive however some criticism of Morris Iemma and Kevin Rudd and their involvement in the event emerged. In the case of Kevin Rudd, the focus was mostly regarding his address at the opening ceremony, whereas Morris Iemma was criticized for an opinion piece where he highlighted the role religion plays in his politics. Also commented on in several letters was the way in which key services, including public transport and disability services were working so well and questioning why this was not normally the case. Another letter to the editor was from a resident supportive of the event even though he was not religious. There were "NoToPope" protestors but the Daily Telegraph did not give this excessive coverage, just stating that they were drowned out by the pilgrims and the condoms they were handing out were thrown back to the protestors by the pilgrims. The Telegraph did mention the intolerance of the $\mathrm{ABC}$ radio and television and Fairfax media to the event.

During WYD the Sydney Morning Herald seemed to warm to event, as their coverage was not as negative as it had previously been. News coverage in relation to the event covered a broader range of issues than those included in the Daily Telegraph. Two significant issues covered were in relation to pilgrim visas and detaining of some pilgrims. Included were stories of how some residents and local businesses were benefiting from the event such as camping stores (Huxley, 2008). However, there was still a degree of negativity in many of the stories, as the following headlines demonstrate "Leave your cars at home" (Bessor, 2008) and "Long Marches Await Weary Pilgrims" (Besser, 2008). Even though the feature articles were becoming more balanced towards the event, if not quite positive, the letters to the editor that were selected were predominantly negative: congratulations to the protestors, the Catholic Church 
is outdated, anti the event as non-Christians are not welcome. One letter stated that it is not to the pilgrims to deal with the negativity in the media.

National Media. The Australian continued to be predominately positive in their coverage during the event. Like the Daily Telegraph, their news coverage focused primarily on the actual events and the pilgrims attending these events. There was one article expressing disappointment that the Pope had not apologized for the sexual abuse by Catholic clergy and religious. They also included a lengthy feature article on July 17 th regarding the motivation of anti-pope protesters, which was attributed to stemming from the old Protestant/Catholic divide (Burchell, 2008). A second feature of particular interest was included in the Weekend Australian on July 19th. This feature noted the turnaround in attitudes toward the event and attributed this to the excellent behavior of the pilgrims (Livingstone, 2008).

Community Feedback. The general comments by locals during the event were positive and the event was likened to the Olympics, "you know the buzz of the Olympics being repeated again." The event ran smoothly "Everybody has just been so harmonious, you know giving and taking and even sharing with people they don't know, the global village is here and getting along with one another. Everyone has been really united and positive, and everywhere I go other locals and visitors are so cooperative."

One of the potential impacts of the event on residents noted by some of the media was visitors clogging the local transport system. Sydney commuters commented to the researcher that the pilgrims had had no impact. One railway guard at Pennant Hills railway station said "No hassles, everything is moving, no one is waiting for the trains, everyone is happy and smiling. Even the locals are smiling and nice to me and not abusing or complaining to me." He said, "I think we should have an event like this every month because it keeps our locals happy as well, it is really contagious, the cheerful atmosphere and environment." As the event progressed many residents commented how, after capturing the atmosphere through TV broadcasts or word of mouth, they de- cided to come into the city to partake in the various events. One North Sydney employee said "People have been telling what a buzz the city is just to go in, and I'm going to take a walk tonight, over the bridge just to get, to feel the atmosphere." Two police officers involved directly with the pilgrims and the event had the following to say: "There have been no problems it has been no great effort on our part, we are having fun with the crowd, I wish every job was like this."

\section{Media Coverage After the Event}

Local Media. The Daily Telegraph remained positive in coverage of the event right up until the end of July. The 2 days following the event contained comprehensive coverage of the final mass, the final blessing, and the Pope's departure. Coverage included the pilgrim who was assaulted at Randwick, the clean-up of Randwick racecourse, and the tasks still to be completed by Bishop Anthony Fisher who was responsible for organizing the event. They also included a special tribute to the volunteers, and published the names of all 8000 volunteers on July 26th.

Coverage of the final events of WYD08 by the Sydney Morning Herald was comprehensive; however, a degree of negativity was apparent in the way in which they covered stories after the event. This was evident in range of articles that covered the "uproar" over the cancellation of the Pope's tour of centennial park (Harvey, 2008), the Catholic Church being out of pocket \$15-20 million (Morris, 2008a), and questioning if the Church will be able to capitalize in the longer term (Morris, 2008b). Several articles also highlighted the cost to residents of hosting the event including the article that stated the retail sector did not feel they had benefited (Emerson, 2008) and how Church delays resulted in \$2.4 million being wasted installing temporary smoke detectors and showers in schools (Jensen, 2008). An article on July 21 stated that the event was successful but was critical of the Catholic Church. Another article on the same day commented on the success of the event and thanked the pilgrims who made the event. The letters to the editor were still predominantly critical but no new issues were raised. 
National Media. In the 11 days following the event, the Australian had only a few articles related to World Youth Day. The 21st and 22nd of July contained eight articles providing a wrap up of the event. These were all positive in tone highlighting how successful the event was. The following edition of the Weekend Australian also contained two articles stating how successful the event was. Apart from one article that highlighted some criticisms of the Pope's meeting with four victims of sexual abuse after the event had finished and one gossip column that stated that the Pope smokes cigarettes, no other coverage was provided.

Community Feedback. A couple stated "We live in Sydney but did not participate in anything. But World Youth Day was wonderful, seeing all these young people so positive, and the fact that there was not one incident reported in the news that we are aware of. Being an elderly retired couple it gives us such hope for the youth, that this number, such a huge number can come together and not have any incidents." One of the airport services staff at the International airport was asked to comment on her views of the pilgrims: "They are wonderful, it is once again one of the busiest days in the airport but they are so respectful, kept the place clean, it is pleasure to be around them."

Galaxy/Pure Profile Poll. Table 1 shows the results of the Galaxy/Pure Profile poll taken in the days immediately following the conclusion of WYD08. The results of this poll clearly indicated the majority of residents surveyed believed WYD08 was a good thing for Sydney and that the event was well organized. Just over half of the respondents believed Sydney should offer to host the event again.

\section{Discussion and Conclusion}

In analyzing the print media there is evidence that there was good event planning and management on behalf of the event organizers and this was supported by the poll. Extensive information was provided through the print media on bus, train, and ferry services, maps of walking routes, road closures, and detailed event information. An interesting point to note regarding the newspapers discussed above is the ownership of these newspapers. Fairfax limited owns both Sydney Morning Herald and the Age, the media that were predominately negative in their coverage prior to the event. The Daily Telegraph and the Australian are owned by News Limited.

The media prior to the event did focus controversially on the economic costs while the economic benefits were promoted by the government, the tourism sector, and the event organizers. The coverage of the social-cultural impacts by the media prior to the event was restricted to congestions, disruption to public transport, and road closures. Letters to the editor during the event noted the lack of disruption. The social-cultural impacts were chiefly positive with local community civic pride, self-esteem, caught up in the festive atmosphere with a fond reminiscence of the Olympics. There were road closures but the event was well managed and significant importance was placed on social-cultural impacts by the event organizers. The media appeared to perceive impacts prior to the event to be greater than what actually hap-

Table 1

Poll Findings

Do you think WYD was a good thing or a bad thing for Sydney? Good thing: $71 \%$ Bad thing: $12 \%$

Compared with your expectation before the event, how would you describe the inconvenience of having so many visitors?

Do you think the organizers of WYD did a good job or a poor job?

Do you agree that it was good to see so many young people enjoying themselves without creating a nuisance?

$\begin{array}{clc}\begin{array}{c}\text { Not as bad as } \\ \text { expected: } 54 \%\end{array} & \begin{array}{c}\text { Just as } \\ \text { expected: } 34 \%\end{array} & \begin{array}{c}\text { Worse than } \\ \text { expected: } 12 \%\end{array} \\ \text { Good job: } 78 \% & \text { Poor job: } 9 \% & \text { Uncommitted: } 13 \%\end{array}$

Agree: $81 \%$ Disagree: $6 \% \quad$ Uncommitted: $13 \%$ 
pened that supports S. S. Kim and Petrick (2005) and Twynam and Johnston (2004) findings in relation to residents' perception of impacts. The exposure in the media of the environmental impacts was quite small in context especially prior to and during the event with only one article on the WYD2008 carbon emissions offset scheme and another on the clean up after the event.

The research supports Fredline and Faulkner (2001) findings that high levels of contact with the event tend to lead to more extreme positions. Residents who came in contact with the researcher around the event exhibited extreme positions in relation to the event, mostly supportive. It needs to be acknowledged however that these data were ad hoc and a limitation of the research is that there were no formal and systematic data collected regarding residents perception of the event besides the Galaxy Poll (see Table 1). The findings of this article conflict with those of Allon's (2004) and Scott and Smith's (2005), highlighting residents' antagonism, yet all three studies involved young people. The negative media reports, especially prior to the event, did not reflect a decline in community support. This difference in this study is that the pilgrims were well behaved and their cheerful carnival environment they created was welcomed by the residents. The subjects in the other two studies exhibited disruptive behavior. This is perhaps due to the different types of "tourists," one group characterized by hedonistic pleasure seeking school leavers/backpackers and the other group seeking a spiritual experience. An avenue for further research is to examine event participant behavior and subsequent impact on community support for the event.

The media was relatively silent regarding community support for the event. The local community did take ownership as represented by government authorities, police, transport, health, officially registered volunteers, families who hosted pilgrims, donations of clothing and blankets for pilgrims from tropical climates, and unofficial volunteers who helped WYD organizers in a range of tasks such as packaging food. Only one newspaper acknowledged the volunteers postevent. The findings demonstrate the urban festival atmosphere that took hold of Sydney during the event, which signifies community engagement with the event but this was blurred among other media stories around WYD2008.

This investigation provides evidence of the media attempting to find an unusual angle or use of sensationalism in order to break through the "media noise" by all three newspapers. Issues were raised unrelated to the actual event such as sex scandals in the Catholic Church, the Catholic Church is outdated, tension between the Catholic Church and other Christian Churches, political party views, or personalities. Research exists providing evidence of a bias in the media against conservative religious issues and the "culture wars" played out through the media (Bolce \& De Maio, 2008; Glascock, Livesay, \& Ruggiero, 2008). Journalists have been found to be typically secularist, liberal, and on the left hand side of the political divide (Underwood, 2002). A religiously orientated event such as World Youth Day was used, in this case, as another vehicle to continue the culture wars in the media, therefore mitigating the media as representative of community acceptance of the event. This was explicitly evidenced by the Sydney Morning Herald's treatment of the event and journalists from other newspapers and the letters to the editor accusing specific journalists of their bias. It is noted however that it is difficult to take an event out of the wider social-cultural context which typifies tourism research.

This article supports Hoffman et al.'s (2007) findings that the media has dual roles: shaper of public opinion and reflector of public opinion. There is evidence that the positive community's response to the event and the event participants shaped the media during the event. Yet prior to and after the event the media took on the role of shaping public opinion through agenda setting and media framing (Perry, 1996; Rosenberry \& Vicker, 2009). An area of further research could be close monitoring of the interplay between the event, the community, and the media. It is also suggested that further research be conducted between connectedness, alignment, and influence between the perception of the negative impacts of events by both media and residents in the lead up to the event.

Public opinion measured through a galaxy poll, postevent, showed residents to be favorable to the event and the pilgrims. Herbst (2001) argues that 
public opinion is measured through polls and Moala (2005) argues that the media should only be a reflection of public opinion. In this case, after the event the Daily Telegraph appears to be a mirror, while the Sydney Morning Herald resorted back to critical reviews of the event and the Australian through its silence was not interested in reflecting public opinion at all. This study would argue that the media do not accurately reflect community views towards an event. However, more research is required to examine the relationship between media and community acceptance of the event. It would be recommended that future research selects an event that can be distanced from ideological controversy.

\section{References}

Allon, F. (2004). From visiting cultures to travelling cultures: Local communities' backpacker tourism, and the consumption of authenticity in Sydney. Tourism, 52(1), $65-73$.

Ancient Pilgrim Path Leads Down Under. (2008, July 12). The Weekend Australian. Retrieved January 29, 2009, from http://search.ebscohost.com/login.aspx?direct=true $\& \mathrm{db}=$ nfh\&AN $=200807141007808615 \&$ site=ehost-live

Bazeley, P. (2003). Computerized data analysis for mixed methods research. In A. Tashakkori \& C. Teddle (Eds.), Handbook of mixed methods in social science \& behavioral research (pp. 385-422). Thousand Oaks, CA: Sage Publications.

Besser, L. (2008, July 19). Long marches await weary pilgrims. The Sydney Morning Herald. Retrieved from http://search.ebscohost.com/login.aspx?direct=true $\& \mathrm{db}$ $=$ anh \& AN=SYD-5KXS2PX9GFS10G1R61GQ $\&$ site $=$ ehost-live

Bolce, L., \& De Maio, G. (2008). A prejudice for the thinking classes: Media exposure, political sophistication, and the anti-Christian fundamentalist. American Politics Research, 36, 155-185.

Bowdin, G., Allen, J., O’Toole, W., Harris, R., \& McDonnel, I. (2006). Events management (2nd ed.). Oxford: Butterworth-Heinemann.

Burchell, D. (2008, July 17). Pilgrims and atheists cut from same cloth. The Australian. Retrieved January 29, 2009, from http://search.ebscohost.com/login.aspx?direct=true $\& \mathrm{db}=$ nfh \&AN $=200807141007808615 \&$ site $=$ ehost-live

Burton, R. (2003). Olympic Games host city marketing: An exploration of expectations and outcomes. Sport Marketing Quarterly, 12(1), 37.

Chalip, L. (2004). Beyond impact: A general model for sport event leverage. In B. W. Ritchie \& D. Adair (Eds.), Sport tourism: Interrelationships, impacts, and issues (Vol. 14, pp. 226-252). Clevedon, UK: Channel View Publications.

Creswell, J. W., \& Plano Clark, V. L. (2007). Designing and conducting mixed methods research. Thousand Oaks, CA: Sage Publications.

Custadio, M. J. F., \& Gouveia, P. M. D. C. B. (2007). Evaluation of the cognitive image of a country/destination by the media during the coverage of mega-events: The case of UEFA EURO 2004 in Portugal. International Journal of Tourism Research, 9(4), 285-296.

D'Alessio, D. (2003). An experimental examination of readers' perceptions of media bias. Journalism \& Mass Communication Quarterly, 80(2), 282-294.

Deccio, C., \& Baloglu, S. (2002). Non-host community residents' reaction to the 2002 Winter Olympics: The spillover impacts. Journal of Travel Research, 41, 46-56.

Devine, F. (2008, July 11). Ferals will learn you can't bash beatitude out of pilgrims. The Australian. Retrieved January 29, 2009, from http://search.ebscohost.com/ login.asp ?direct=true $\& \mathrm{db}=\mathrm{nfh} \& \mathrm{AN}=20080714100780$ $8615 \&$ site $=$ ehost-live

Emerson, D. (2008, July 22). What tourism mojo? Shops still skeptical. The Sydney Morning Herald. Retrieved July 27, 2008, from http://search.ebscohost.com/login .aspx ?direct $=$ true $\& d b=$ anh $\& A N=S Y D-5 K Z C Z Y K 8 D P$ S150TUO1GQ\&site=ehost-live

Evans vs. State of New South Wales. (2008). Federal Court of Australia.

Events NSW. (n.d.). Events strategy. Retrieved February 20, 2009, from http://www.eventsnsw.com.au/events_ strategy/

Falkheimer, J. (2007). Events framed by the mass media: Media coverage and effects of America's Cup preregatta in Sweden. Event Management, 11(1/2), 81-88.

Fredline, E. (2004). Host community reactions to motorsport events: The perception of impact on quality of life. In B. W. Ritchie \& D. Adair (Eds.), Sport tourism: Interrelationships, impacts, and issues (Vol. 14, pp. 155173). Clevedon, UK: Channel View Publications.

Fredline, E., \& Faulkner, B. (2001). Variations in residents' reactions to major motorsport events: Why residents perceive the impacts of events differently. Event Management, 7, 115-125.

Galaxy Research. (n.d.). About. Retrieved May 8, 2009, from http://www.galaxyresearch.com.au/index.php?page =about

Getz, D. (1997). Event management \& event tourism. New York: Cognizant Communication Corporation.

Getz, D. (2007). Event studies: Theory, research, and policy for planned events. Oxford: Butterworth-Heinemann.

Glascock, J., Livesay, C. B., \& Ruggiero, T. E. (2008). Religious involvement, audience demographics, and media bias. Journal of Media \& Religion, 7(4), 256-270.

Gursoy, D., \& Kendall, K. W. (2006). Hosting mega events: Modeling locals' support. Annals of Tourism Research, 33(3), 603-623.

Hall, C. M. (1992). Hallmark tourist events: Impacts, management, and planning. London: Belhaven Press.

Hall, C. M. (2001). Imaging, tourism, and sports event fever: The Sydney Olympics and the need for a social 
charter for mega-events. In C. Gratton \& I.P. Henry (Eds.), Sport in the city: The role of sport in economic and social regeneration (pp. 166-183). London: Routledge.

Hall, C. M., \& Hodges, J. (1996). The party's great, but what about the hangover?: The housing and social impacts of mega-events with special reference to the 2000 Sydney Olympics. Festival Management \& Event Tourism, 4(1-2).

Harvey, E. (2008, July 21). Centennial Park scratched for the XVIth at Randwick. The Sydney Morning Herald. Retrieved July 27, 2008, from http://search.ebscohost. com/login.aspx direct $=$ true $\& \mathrm{db}=\overline{\mathrm{anh}} \& \mathrm{AN}=\mathrm{SYD}-5 \mathrm{KYU}$ F8UK5QS1DICBZ1GQ\&site=ehost-live

Hede, A.-M. (2007a). Managing special events in the new era of the triple bottom line. Event Management, 11, 13-22.

Hede, A. (2007b). Mega-events and the "showcase" effect: Investigating the moderating influence of exposure to the 2004 Olympic Games telecast and interest in the Olympic movement-An Australian perspective. Tourism Review International, 10(4), 241-255.

Herbst, S. (2001). Public opinion infrastructures: Meanings, measures, media. Political Communication, 18(4), 451464.

Hiller, H. H. (1995). Conventions as mega-events: A new model for convention-host city relationships. Tourism Management, 16(5), 375-379.

Hoffman, L. H., Glynn, C. J., Huge, M. E., Sietman, R. B., $\&$ Thomson, T. (2007). The role of communication in public opinion processes: Understanding the impacts of intrapersonal, media, and social filters. International Journal of Public Opinion Research, 19(3), 287-312.

Huxley, J. (2008, July 18). "Tis' the winter of their discount tent. The Sydney Morning Herald. Retrieved January 29, 2009, from http://search.ebscohost.com/login. aspx?direct $=$ true $\& \mathrm{db}=\overline{\mathrm{anh} \& \mathrm{AN}=\mathrm{SYD}-5 \mathrm{KXAYD} 4 \mathrm{FA} 5 \mathrm{C}}$ PGOJV1GQ\&site=ehost-live

Jensen, E. (2008, July 28). Church delay may have wasted $\$ 2.4 \mathrm{~m}$. The Sydney Morning Herald. Retrieved August 2, 2008, from http://search.ebscohost.com/login.aspx? direct $=$ true $\& \mathrm{db}=\overline{\text { anh } \& A N=S Y D-5 K Z C Z Y K 8 D P S 150 T}$ UO1GQ\&site=ehost-live

Jeong, G.-H., \& Faulkner, B. (1996). Resident perceptions of mega-event impacts: The Taejon International Exposition case. Festival Management \& Event Tourism, 4, $3-11$.

Johnsen, J., Bieger, T., Elsasser, H., \& Muller, H. (2004). Sustainability of mega events: Challenges, requirements, and results. The case-study of the World Ski Championship St. Moritz 2003. Tourism Review, 59(4), 27-36.

Kang, Y. S., \& Perdue, R. (1994). Long-term impact of a mega-event on International tourism to the host country: A conceptual model and the case of the 1988 Seoul Olympics. In M. Uysal (Ed.), Global tourist behavior (pp. 205-226). New York: International Business Press.

Kasimati, E. (2003). Economic aspects and the Summer
Olympics: A review of related research. International Journal of Tourism Research, 5(6), 433-444.

Kim, H. J., Gursoy, D., \& Lee, S.-B. (2006). The impact of the 2002 World Cup on South Korea: Comparisons of pre- and post-games. Tourism Management, 27(1), 86-96.

Kim, S. S., \& Petrick, J. F. (2005). Residents' perceptions on impacts of the FIFA 2002 World Cup: The case of Seoul as a host city. Tourism Management, 26(1), 25-38.

Lee, C.-K., Lee, Y.-K., \& Lee, B. (2005). Korea's destination image formed by the 2002 World Cup. Annals of Tourism Research, 32(4), 839-858.

Letters to the Editor. (2008, July 14). The Australian. Retrieved January 29, 2009, from http://search.ebscohost. com $/$ login.aspx ?direct $=$ true $\& d b=\overline{n f h} \& A N=2008071410$ $07808615 \&$ site $=$ ehost-live

Lim, S. T., \& Lee, J. S. (2006). Host population perceptions of the impact of mega-events. Asia Pacific Journal of Tourism Research, 11(4), 407-421.

Livingstone, T. (2008, July 19). Flags of enduring loyalty. The Australian. Retrieved January 29, 2009, from http:// search.ebscohost.com/login.aspx ?direct $=$ true $\& \mathrm{db}=\mathrm{nfh} \&$ $\mathrm{AN}=200807141007808615$ \& site=ehost-live

Mitrook, M. (2003). A longitudinal time series analysis of the Foreign Affairs Issue: Agendas of the President, the media, the public. Paper presented at the International Communication Association Annual Meeting. Retrieved from http://search.ebscohost.com/login.aspx?direct=true $\& \mathrm{db}=\mathrm{ufh} \& \mathrm{AN}=16028359$ \&site=ehost-live

Moala, K. (2005). The case for Pacific media reform to reflect island communities. Pacific Journalism Review, 11(1), 26-35.

Morgan, N., Pritchard, A., \& Pride, R. (2002). Destination branding: Creating the unique destination proposition. Oxford: Elsevier Butterworth-Heinemann.

Morris, L. (2008a, July 22). Costs up, but flock's hip pocket is safe. The Sydney Morning Herald. Retrieved July 27, 2008, from http://search.ebscohost.com/login. aspx ?direct $=$ true $\& \mathrm{db}=\overline{\mathrm{anh} \& \mathrm{AN}=\mathrm{SYD}-5 \mathrm{KZD} 02 \mathrm{QPEAC}}$ 16E23A1GQ\&site=ehost-live

Morris, L. (2008b, July 22). First the fervor, now the reckoning. The Sydney Morning Herald. Retrieved July 27, 2008, from http://search.ebscohost.com/login.aspx?di rect $=$ true $\& \mathrm{db}=\overline{\mathrm{anh} \& \mathrm{AN}=\mathrm{SYD}-5 \mathrm{KYU} 34 \mathrm{C03QO1BLI8A}}$ 1GQ\&site=ehost-live

New South Wales Government. (2008). World Youth Day Regulation 2008. Retrieved February 20, 2009, from http://www.legislation.nsw.gov.au/viewtop/inforce/sub ordleg $+32+2008+\mathrm{cd}+0+\mathrm{Y} / \mathrm{dq}=$ Regulations $\% 20$ under $\%$ 20World\%20Youth\%20Day\%20Act $\% 202006 \% 20 \mathrm{No} \%$ 20106

Parliament of New South Wales. (2006). World Youth Day Bill 2006. Retrieved February 20, 2009, from http://www. parliament.nsw.gov.au/prod/PARLMENT/NSWBills.nsf/ 1d4800a7a88cc2abca256e9800121f01/0c0540df3c4adc f3ca257226001dce8c!OpenDocument

Perry, D. K. (1996). Theory and research in mass commu- 
nication: Contexts and consequences. New Jersey: Lawrence Erlbaum Associates.

Peter, J. (2004). Our long "return to the concept of powerful mass media" - A cross-national comparative investigation of the effects of consonant media coverage. International Journal of Public Opinion Research, 16(2), 144-168.

Powell, S. (2008, July 3). Priest denounces heavy-handed "annoyance" code. The Australian. Retrieved January 29, 2009, from http://search.ebscohost.com/login.aspx ?direct $=$ true $\& \mathrm{db}=\mathrm{nfh} \& \mathrm{AN}=200807141007808615 \&$ site $=$ ehost-live

Price Waterhouse Cooper. (2002). Business and economic benefits of the Sydney 2000 Olympics. Retrieved July 31, 2008, from http://fulltext.ausport.gov.au/fulltext/ 2002/nsw/benefitssydney2000.asp

Pure Profile. (2009). Pure summary. Retrieved May 8, 2009, from http://pure-advertising.com/What_we_do/ pure_summary.aspx

Reid, G. (2006). The politics of city imaging: A case study of the MTV Europe Music Awards Edinburgh 03. Event Management, 10(1), 35-46.

Ritchie, J. R. B. (2000). Turning 16 days into 16 years through Olympic legacies. Event Management, 6(3), $155-165$.

Rivenburgh, N., Louw, E., Loo, E., \& Mersham, G. (2004). The Sydney Olympics and foreign attitudes towards Australia. Gold Coast: CRC for Sustainable Tourism.

Rosenberry, J., \& Vicker, L. A. (2009). Applied mass communication theory: A guide for media practitioners. Boston: Pearson Education.
Scott, N., \& Smith, A. E. (2005). Use of automated content analysis techniques for event image assessment. Tourism Recreation Research, 30(2), 87-91.

Strauss, A., \& Corbin, J. (1990). Basics of qualitative research: Grounded theory procedures and techniques. Newbury Park, CA: Sage Publications.

Sydney Chamber of Commerce. (2008). World Youth Day 2008 business briefing. Sydney: Sydney Chamber of Commerce. Document Number

Toohey, K., \& Veal, A. J. (2007). The Olympic Games: A social science perspective (2nd ed.). Oxfordshire: $\mathrm{CAB}$ International.

Twynam, G. D., \& Johnston, M. (2004). Changes in host community reactions to a special sporting event. Current Issues in Tourism, 7(3), 242-261.

Underwood, D. (2002). From Yahweh to Yahoo! The religious roots of mass media and the rise of the skeptical press. Urbana: University of Illinois Press.

Vliegenthart, R., Schuck, A. R. T., Boomgaarden, H. G., \& De Vreese, C. H. (2008). News coverage and support for European integration, 1990-2006. International Journal of Public Opinion Research, 20(4), 415-439.

Whitson, D., \& Macintosh, D. (1993). Becoming a worldclass city: Hallmark events and sport franchises in the growth strategies of western Canadian cities. Sociology of Sport Journal, 10(3), 221-240.

World Youth Day 2008. (2008). Final WYD08 statistics. Sydney.

World Youth Day Coordination Authority. (2008). Fact sheet. Retrieved July 31, 2008, from http://www. wydca.nsw.gov.au/ 